\title{
Bacterial contamination of cotton and cotton dust and effects on the lung
}

\author{
R. RYLANDER AND M. LUNDHOLM \\ From the Department of Environmental Hygiene, University of Gothenburg, Sweden
}

ABSTRACT Bacterial contamination of various parts of the cotton plant and of cotton from different mills was investigated. The predominant bacterial species were Gram-negative rods mainly of the Enterobacter genus. When guinea pigs inhaled strains of these bacteria cultivated from cotton, a strong leucocyte mobilising capacity was found for Pseudomonas and Enterobacter but not for Agrobacterium or Bacillus species. The aetiology of the development of pulmonary symptoms after inhalation of bacteria-containing dusts and subsequent production of endotoxins is discussed.

The presence of airborne Gram-negative bacteria in cotton mills was first reported by a commission investigating working conditions in cotton mills in Great Britain (Home Office, 1932). The importance of the bacterial contamination of cotton dust in the development of pulmonary symptoms after acute and subchronic exposure has since been investigated by several workers. Schneiter et al. (1942) found up to $10^{7}$ colonies per gram of cotton sampled from different mills. Bacterial strains of the genus Enterobacter were found in cotton materials reported to have adversely affected exposed workers. An endotoxin-like substance was demonstrated in filtrates from saline extracts of stained cotton.

Pernis et al. (1961), and Cavagna et al. (1969), suggested bacterial endotoxin as a causative agent in occupational disease following the inhalation of vegetable dusts, particularly cotton dusts. This hypothesis was rejected by Antweiler (1961) and results from in vivo and in vitro experiments reported by Tuffnell (1960) did not incriminate bacteria in the development of pulmonary symptoms.

In animals, acute or chronic exposure to water extracts of bale cotton, bract or a bract aerosol will cause an increase in the number of polymorphonuclear leucocytes (PMN) in the airways a few hours after exposure (Rylander and Nordstrand, 1974). This increase reaches a peak at 24 hours after exposure, with a subsequent decline in PMN. During a three-week exposure period the number of PMN remained at an increased level but fell within a

Received for publication 20 September 1977

Accepted for publication 18 January 1978 few days of cessation of exposure (Rylander and Snella, 1976). The leucocyte mobilising reaction occurs in several different animal species (Walker et al., 1975) and in man (Merchant et al., 1975).

A close correlation was found between the number of airborne Gram-negative bacteria and the prevalence of byssinosis in an epidemiological study in different cotton mills (Cinkotai et al., 1977).

In view of the apparent importance of the bacterial contamination of cotton in the development of pulmonary symptoms, the bacteria on different cotton plants and bale cotton were studied. The number of viable bacteria and the species were determined. The reactions after acute exposure to bacteria typically found on cotton were studied in animal experiments.

\section{Materials and methods}

BACTERIAL CULTURE OF COTTON

Samples of cotton plants, bale cotton and cotton from blending machines, card rooms and waste from cards were collected from different cotton mills. One gram of the sample was suspended in $\mathbf{1 0}$ $\mathrm{ml} 0.9 \% \mathrm{NaCl}$ and shaken vigorously. The liquid was squeezed out of the sample, then put back and shaken again. Serial dilutions of the extracts were plated on nutrient agar, blood agar or Drigalski agar selective for Gram-negative rods and incubated at $37^{\circ} \mathrm{C}$ overnight. The total number of colony-forming units (cfu) was counted. Pilot experiments showed that incubation at $20^{\circ} \mathrm{C}$ and $30^{\circ} \mathrm{C}$ gave the same number of cfu.

All samples were prepared in duplicate and the results were expressed as the mean number of $\mathrm{cfu} / \mathrm{g}$ 
material. The cfu on Drigalski agar is referred to as the number of Gram-negative bacteria.

Bacterial colonies from the Drigalski agar plates were selected for further studies according to their morphological appearance. Standard microbiological and biochemical techniques were used for species determination.

INHALATION TOXICITY

Guinea pigs were exposed to an aerosol of the most common strains of bacteria isolated from cotton. The different bacterial strains studied were suspended in distilled water in a Collison spray at a concentration of about $10^{9}$ bacteria/ml (Rylander, 1968). Animals were exposed to an aerosol spray of the suspension for 40 minutes. About $2.7 \times 10^{5}$ viable bacteria were found in the animals' lungs after exposure.

The number of cells in the airways was determined by lavage 24 hours after exposure (Rylander, 1971). The animals were killed with an intraperitoneal injection of thiopentone sodium and the trachea was opened. A syringe was connected to the trachea and $10 \mathrm{ml}$ of sterile saline was gently flushed into the lungs. The fluid was withdrawn into the syringe and flushed into the lungs again. This procedure was repeated 10 times, after which the fluid was transferred from the syringe into a glass vial and stained with Türck's solution. The number of cells in the preparation was counted under a microscope and a differential count was made between pulmonary alveolar macrophages (PAM) and polymorphonuclear leucocytes (PMN).

\section{Results}

\section{BACTERIAL CONTAMINATION}

All samples of plants, bales and other raw cotton materials studied contained bacteria in varying quantities, up to a level of $10^{8}$ bacteria/g material. Gram-negative rods generally comprised the majority of bacteria found on the various samples tested. Occasionally up to $50 \%$ of the bacteria were found to be Gram-positive rods. There was no correlation between the number of Gram-negative and Gram-positive bacteria. The samples of card waste usually contained more Gram-negative bacteria than the bale samples or blended cotton. Table 1 shows typical numbers of Gram-negative bacteria in samples of bale cotton of different geographical origin, and in different parts of the cotton plant. The number of Gram-negative rods ranged from about $10^{1}$ to $10^{7}$ per gram material. No bacteria were found on cotton from unopened cotton bolls.
Enterobacter agglomerans and Pseudomonas syringae were found in almost all samples. Agrobacterium spp. were found in about $60 \%$ of the cotton samples investigated. These bacteria may be termed 'typical cotton bacteria'.

Klebsiella and/or Enterobacter cloacae could be found in some samples as could Acinetobacter calcoaceticus, $\boldsymbol{P}$. stutzerii, $\boldsymbol{P}$. maltophilia, $\boldsymbol{P}$. fluorescens and Flavobacterium spp. In addition, small numbers of unidentifiable bacteria were occasionally found in some of the cotton samples.

INHALATION TOXICITY

Inhalation experiments using the different strains of Gram-negative bacteria cultured from cotton showed an increase in the number of leucocytes after exposure to all Gram-negative bacteria examined, with the exception of Agrobacterium spp. (Table 2). Exposure to Bacillus spp. did not influence the number of leucocytes in the lungs. The number of macrophages was also raised by exposure to Gram-negative bacteria, with the exception of Agrobacterium spp.; the number was also unaffected by exposure to Bacillus spp.

\section{Discussion}

The results demonstrate that the cotton products studied were contaminated primarily by Gramnegative bacteria, mainly of Enterobacter, Pseudomonas and Agrobacterium species. These bacteria were also present on the cotton plant itself. This finding corroborates previous reports, such as that by Dutkiewicz (1976), who isolated Enterobacter species from a variety of organic dusts.

Gram-negative bacteria are found in the air of cotton mills (Cinkotai et al., 1977; Rylander et al., 1978). The concentration in the air depends upon the degree of contamination of the raw material, the handling procedures and the ventilation. The same studies demonstrated that the amount of endotoxins in airborne dust from cotton mills ranges from 0.2 to $1.6 \mathrm{mg} / \mathrm{g}$ dust, which is greatly in excess of the level at which symptoms could be provoked in exposed workers.

Exposure to inhaled endotoxins causes several clinical reactions (Kadis et al., 1971). Acute symptoms of fever, chills and malaise may develop. Endotoxins activate complement either via $\mathrm{C}_{3}$ through the properdin pathway or by direct action on $C_{1}$. In the course of these reactions anaphylatoxins and chemotoxins are liberated, together with leucotactic factors, which cause an influx of PMN into the exposed tissue (Mergenhagen et al., 1973).

Endotoxins also activate the Hageman factor, which in turn influences the kallikrein system and 
Table $1 \log _{10}$ number of Gram-negative rods/g material on samples of various cotton products. Values for cotton of differing geographical origin should not be regarded as typical of that region, but merely indicative of the normal variation in values

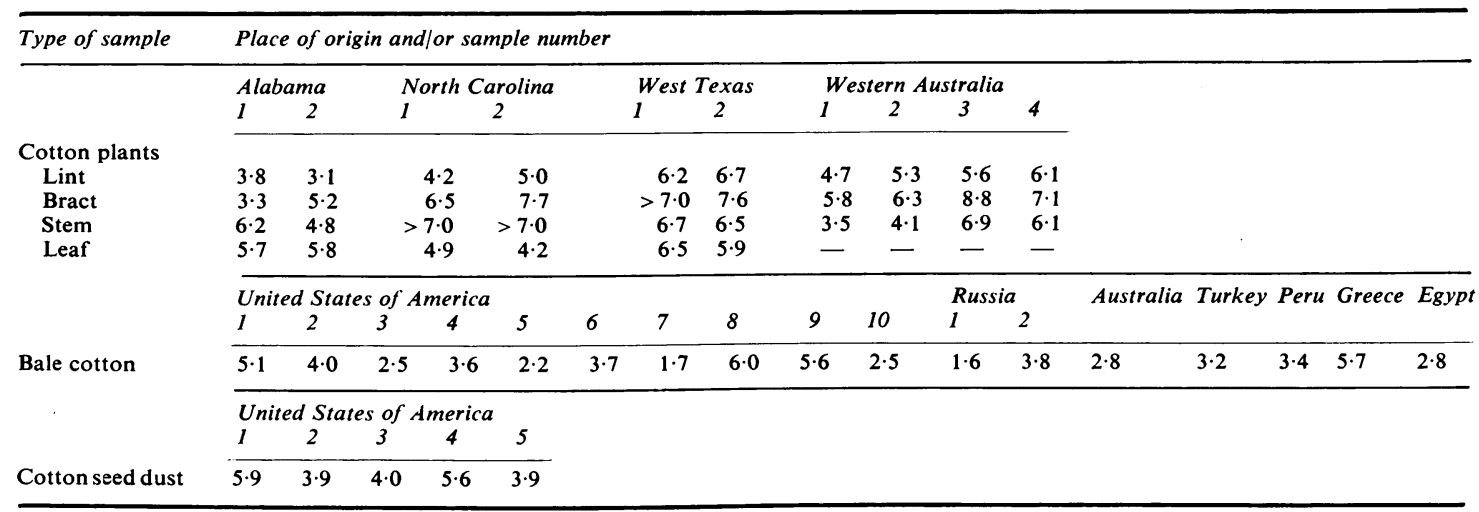

Table 2 Number of macrophages and leucocytes in airways of guinea pigs exposed to aerosols of different bacteria from cotton plants

\begin{tabular}{llll}
\hline Bacteria in aerosol & $\begin{array}{l}\text { Number of } \\
\text { animals }\end{array}$ & $\begin{array}{l}\text { Macrophages } \\
(\text { mean no. } \\
\left.\times 5 \times 10^{4} / \text { lung }\right)\end{array}$ & $\begin{array}{l}\text { Leucocytes } \\
(\text { mean no. } \\
\left.\times 5 \times 10^{4} / \text { lung }\right)\end{array}$ \\
\hline Control & 25 & $145(49)$ & $67(40)$ \\
Enterobacter cloacae & 10 & $452(235)^{* * *}$ & $622(422)^{* * * *}$ \\
Enterobacter agglomerans & 10 & $402(193)^{* * *}$ & $527(204)^{* * *}$ \\
Agrobacterium spp. & 10 & $149(41)$ & $86(32)$ \\
Klebsiella oxytoca & 10 & $407(209)^{* * *}$ & $663(306)^{* * * *}$ \\
Pseudomonas syringae & 10 & $417(186)^{* * *}$ & $596(296)^{* * *}$ \\
Bacillus spp. & 9 & $153(34)$ & $91(32)$ \\
\hline
\end{tabular}

Standard deviation in parentheses. ${ }^{* *}$ Statistically significant difference from control values (Student's $t$ test), $P<0.001$.

other components involved in blood clotting. This may be of practical importance because it has been shown previously that workers exposed to endotoxins in airborne sewage sludge have increased levels of fibrinogen degradation products in their urine (Rylander et al., 1977). No data are available on the excretion of these products by cotton workers.

Tolerance to endotoxin follows prolonged exposure (Wolff, 1973), which explains the disappearance of mill fever among workers in cotton mills. Inhalation of the different Gram-negative bacteria isolated from cotton demonstrated that most species caused an increase in the number of leucocytes in the airways. However, no reaction could be detected after exposure to Agrobacterium species. The reason why this organism, which also produces endotoxins, does not cause an influx of leucocytes in the airways of exposed animals is still not clear. There are structural differences between the endotoxin produced by this bacterium and endotoxins produced from bacteria such as Enterobacter and Klebsiella (Salkinoja, 1977, personal com- munication). Further research is needed to investigate the relationship between such structural differences and the pulmonary toxicity of endotoxins.

From a technical point of view, the number of viable bacteria on cotton can be reduced fairly easily by applying humid heat. However, this process will not influence the activity of endotoxin, and data from animal experiments (Rylander et al., 1975) indicate that heat treatment may increase the inhalation toxicity of a suspension of Gramnegative bacteria or of an extract of cotton dust.

Although the acute pulmonary reactions after exposure to cotton dust and the development of byssinosis appear to be related to the presence of Gram-negative bacteria in the air, further information is needed concerning the exact mechanisms responsible for the development of the disease, before a definite causal relationship can be established. Nevertheless, it may be prudent in the meantime to establish a standard for airborne Gramnegative bacteria, to supplement the existing dust standard.

The authors are grateful for the helpful advice given by Mr Enevold Falsen. The study was supported by the US Department of Agriculture with funds made available by Cotton Incorporated.

\section{References}

Antweiler, H. (1961). Histamine liberation by cotton dust extracts: evidence against its causation by bacterial endotoxins. British Journal of Industrial Medicine, 18, 130-132.

Cavagna, G., Foa, V., and Vigliani, E. C. (1969). Effects in man and rabbits of inhalation of cotton dust or extracts and purified endotoxins. British Journal of Industrial Medicine, 26, 314-321.

Cinkotai, F. F., Lockwood, M. G., and Rylander, R. (1977). Airborne micro-organisms and prevalence of byssinotic 
symptoms in cotton mills. American Industrial Hygiene Association Journal, 38, 554-559.

Dutkiewicz, J. (1976). Studies on endotoxins of Erwinia herbicola and their biological activity. Zentralblatt Bakteriologische Hygiene, 236, 487-508.

Home Office (1932). Report of the Departmental Committee on Dust in Cardrooms in the Cotton Industry. HMSO: London.

Kadis, S., Weinbaum, G., and Ajl, S. J. (1971). Bacterial endotoxins. In Microbiological Toxins, $V$, pp. 1-492. Academic Press: London and New York.

Merchant, J. A., Halprin, G. M., Hudson, A. R., Kilburn, K. H., McKenzie, W. N., Hurst, D. J., and Bermazohn, P. (1975). Responses to cotton dust. Archives of Environmental Health, 30, 222-229.

Mergenhagen, S. E., Snyderman, R., and Phillips. J. K. (1973). Activation of complement by endotoxin. In Bacterial Lipopolysaccharides, pp. 78-82. Edited by E. H. Kass and S. M. Wolff. Chicago University Press: Chicago.

Pernis, B., Vigliani, E. C., Cavagna, G., and Finulli, M. (1961). The role of bacterial endotoxins in occupational diseases caused by inhaling vegetable dusts. British Journal of Industrial Medicine, 18, 120-129.

Rylander, R. (1968). Pulmonary defence mechanisms to airborne bacteria. Acta Physiologica Scandinavica, Suppl. 306, 1-89.

Rylander, R. (1971). Free lung cell studies in cigarette smoke inhalation experiments. Scandinavian Journal of Respiratory Disease, 52, 121-128.

Rylander, R., and Nordstrand, A. (1974). Pulmonary cell reactions after exposure to cotton dust extract. British Journal of Industrial Medicine, 31, 220-223.

Rylander, R., Nordstrand, A., and Snella, M. C. (1975). Bacterial contamination of organic dusts. Archives of Environmental Health, 30, 137-140.

Rylander, R., and Snella, M. C. (1976). Acute inhalation toxicity of cotton plant dust. British Journal of Industrial Medicine, 33, 175-180.

Rylander, R., Andersson, K., Belin, L., Berglund, G., Bergström, R., Hanson, L., Lundholm, M., and Mattsby, I. (1977). Studies on humans exposed to airborne sewage sludge. Schweizerische Medizinische Wochenschrift, 107, 182-184.

Rylander, R., Haglind, P., and Lundholm, M. (1978). Byssinosis, dust levels and airborne bacteria in 5 Swedish cotton mills. Unpublished data.

Schneiter, R., Neal, P. A., and Caminita, B. H. (1942). Etiology of acute illness among workers using low-grade stained cotton. American Journal of Public Health, 10, 13451359.

Tuffnell, P. (1960). The relationship of byssinosis to the bacteria and fungi in the air of textile mills. British Journal of Industrial Medicine, 17, 304-306.

Walker, R. F., Edison, G., and Hatcher, J. D. (1975). Influence of cotton dust inhalation on free lung cells in rats and guinea pigs. Laboratory Investigation, 1, 28-32.

Wolff, S. M. (1973). Biological effects of bacterial endotoxins in man. In Bacterial Lipopolysaccharides, pp. 251-256. Edited by E. H. Kass and S. M. Wolff. Chicago University Press: Chicago. 